\title{
COPOLYMERIZATION OF VINYL CHLORIDE BY ORGANOMETALLIC COMPOUNDS
}

\author{
JUNJI FURUKAWA
}

Department of Synthetic Chemistry, Kyoto University, Kyoto, Japan

\begin{abstract}
The copolymerizations of vinyl chloride with $\alpha$-olefin or acrylic compounds were investigated with organometallic compounds as catalysts. In general, organoaluminium compounds need to be treated with a complexing agent such as tetrahydrofuran prior to use. Otherwise the former reacts with polyvinyl chloride and loses its activity. The copolymer of vinyl chloride and propylene was thus obtained. The properties of the copolymer produced are almost the same as of that produced by conventional radical polymerization.

Vinyl chloride is capable of copolymerizing with acrylonitrile without any complexing agent, since the latter monomer acts as a complexing agent. Transtion metal compounds are useful cocatalysts for enhancing catalytic activity. It was found that the use of equimolar or greater amounts of organoaluminium compounds yields a 1:1-copolymer regardless of monomer composition, whereas a smaller amount of the catalyst produces random copolymers. This fact is interpreted by an assumption that the copolymerization takes place between free acrylonitrile and a ternary complex of vinyl chloride, acrylonitrile and aluminium compound.
\end{abstract}

\section{INTRODUCTION}

The polymerization of polar monomers such as vinyl chloride (VC) with organometallic catalysts offers many problems. The reactivity of organometallic compounds must be controlled to avoid direct attack on polar groups in monomers and polymers. The second problem is to find useful catalysts capable of influencing not only initiation but also propagation steps in order to control stereoregular polymerization and preferential copolymerization or alternating copolymerization.

This paper deals with the polymerization of vinyl chloride and the copolymerization with $\alpha$-olefin and acrylic compounds with the use of organoaluminium compounds as catalysts, which are delicately modified with complexing agents ${ }^{1}$.

The application of Ziegler-type catalysts to the copolymerization of vinyl chloride with $\alpha$-olefin has been reported by several authors (Table 1).

Without complexing agents the result is not always satisfactory, producing a poor yield. The use of complexing agents such as tetrahydrofuran was attempted by Misono ${ }^{4}$, Breslow ${ }^{5}$ and the authors independently. This idea originated from Australian Patent $26889 / 57$. In addition to this we used a mixed Lewis acid of stannic chloride and titanium or vanadium alkoxide and succeeded in regulating the catalytic activity delicately. For example, the 
Table 1. Ziegler-type catalysts for VC polymerization

\begin{tabular}{|c|c|c|c|}
\hline \multicolumn{4}{|l|}{ Without complexing agent } \\
\hline $\mathrm{Ti}(n-\mathrm{BuO})_{4}-\mathrm{EtAlCl}_{2}$ & VC-E & $50^{\circ}$ & Misono et al. $(1966)^{1}$ \\
\hline $\mathrm{Ti}(\mathrm{BuO})_{4}-\mathrm{Et}_{n} \mathrm{AlCl}_{3-n}$ & VC-PP & $30^{\circ}$ & Yamazaki et al. (1966) ${ }^{2}$ \\
\hline $\mathrm{VO}(\mathrm{EtO})_{3}-\mathrm{R}_{n} \mathrm{AlCl}_{3-n}$ & VC-E & $50^{\circ}$ & Misono $(1968)^{3}$ \\
\hline \multicolumn{4}{|l|}{ With complexing agent } \\
\hline Complexing agent & & & Australian Pat. (1957) \\
\hline $\mathrm{THF} \cdot \mathrm{Ti}(n-\mathrm{BuO})_{4}-\mathrm{EtAlCl}_{2}$ & VC-E & $50^{\circ}$ & Misono $(1967)^{4}$ \\
\hline $\mathrm{CCl}_{4}-\mathrm{Et}_{3} \mathrm{Al} \cdot \mathrm{THF}$ & VC & $30^{\circ}$ & Breslow et al. $(1967)^{5}$ \\
\hline $\mathrm{VO}(\mathrm{OR})_{3}-\mathrm{SnCl}_{4}-\mathrm{Et}_{3} \mathrm{Al} \cdot \mathrm{THF}$ & VC and VC-PP & $0^{\circ} \mathrm{C}$ & Author's $(1967)^{6}$ \\
\hline
\end{tabular}

vanadyl alkoxide - stannic chloride - triethylaluminium - tetrahydrofuran (THF) system was found to be one of the best catalysts, capable of polymerizing and copolymerizing vinyl chloride even at $0^{\circ} \mathrm{C}$. The catalyst yielded the colourless polymer with a high degree of polymerization. Our catalyst system, unlike a simple Ziegler-type catalyst, induces a random copolymerization of vinyl chloride and propylene with a different monomer reactivity ratio compared to that from a conventional radical polymerization.

We extended our catalyst systems to the copolymerization of vinyl chloride and acrylic monomers. In this case acrylic monomers also act as complexing agents when they are used before the mixing of the vanadyl compound. We found that the alternating copolymer was produced if an equimolar or greater amount of the aluminium compound than the acrylic monomer was used, irrespective of feed monomer composition. Otherwise we have random copolymers.

\section{POLYMERIZATION OF VINYL CHLORIDE}

We found excellent catalyst systems composed of vanadyl alkoxide, alkylaluminium - THF, and Lewis acid for the vinyl chloride polymerization. Among various Lewis acids, stannic chloride together with vanadyl or titanium alkoxide gives the best result. Simple uses of Lewis acid such as iron, titanium, tin, molybdenum, cobalt, nickel, and tungsten compounds

Table 2. VC-polymerization $\left(0^{\circ} \mathrm{C}, 24 \mathrm{hr}\right) \mathrm{Et}_{3} \mathrm{Al} \cdot \mathrm{THF}-$ Cocatalyst $1: x$ polymerizes VC.

\begin{tabular}{lccll}
\hline \multicolumn{1}{c}{ Cocatalyst } & $Y$ & $\begin{array}{l}\eta_{s p} / c \\
(\mathrm{dl} / \mathrm{g})\end{array}$ & $\begin{array}{l}{[\mathrm{Cl}]} \\
(\%)\end{array}$ \\
\hline $\mathrm{VO}(t-\mathrm{BuO})_{3}-\mathrm{SnCl}_{4}$ & $\begin{array}{c}x \\
2.6: 7.9 \\
4: 5\end{array}$ & $\begin{array}{c}8.42 \\
6.66\end{array}$ & $\begin{array}{l}0.80 \\
\text { powder }\end{array}$ & $\begin{array}{l}56.85 \\
\text { white }\end{array}$ \\
\hline $\mathrm{Ti}(n-\mathrm{BuO})_{4}-\mathrm{SnCl}_{4}$ & $2.6: 7.9$ & 7.34 & 0.62 & 56.85 \\
\hline $\mathrm{VO}(t-\mathrm{BuO})_{3}$ & 7.9 & 2.70 & 0.31 & 56.75 \\
\hline
\end{tabular}

$\mathrm{Et}_{3} \mathrm{Al}$. THF-- $\mathrm{Fe}(\mathrm{OEt})_{3}, \mathrm{Ti}(n-\mathrm{BuO})_{4}, \mathrm{SnCl}_{4}, \mathrm{Mo}(\mathrm{OEt})_{2} \mathrm{Cl}_{3}, \mathrm{Co}(\mathrm{OEt})_{2}$, $\mathrm{Ni}(\mathrm{MeO})_{2}, \mathrm{~W}(\mathrm{OPh})_{6}$, are inactive. 


\section{COPOLYMERIZATION OF VINYL CHLORIDE}

are almost ineffective (Table 2). In any case triethylaluminium should be complexed with an equimolar amount of THF.

Various kinds of Lewis acid are combined with vanadyl and titanium alkoxides (Table 3). Chlorides of $\mathrm{Sn}, \mathrm{Ge}, \mathrm{Si}, \mathrm{Se}, \mathrm{Sb}$, and $\mathrm{V}$ or $\mathrm{BF}_{3}$ possess similar activities, although chlorides of $\mathrm{Al}, \mathrm{B}, \mathrm{Ti}, \mathrm{Mo}, \mathrm{W}$, and $\mathrm{Fe}$ are inactive. $\mathrm{SnCl}_{2}$ is also inactive.

Table 3. VC-polymerization $\left(0^{\circ} \mathrm{C}, 20 \mathrm{hr}\right)$

$\mathrm{Et}_{3} \mathrm{Al} \cdot \mathrm{THF}-\mathrm{VO}(t-\mathrm{BuO})_{3}$ - Lewis acid $1: 3 \quad: 6$

(or $\left.\mathrm{Ti}(n-\mathrm{BuO})_{4}\right) \quad 1: 2.6: 7.9$

\begin{tabular}{cccc}
\hline & $\begin{array}{c}\text { Conv. } \\
(\%)\end{array}$ & $\begin{array}{c}\eta_{s p} / c \\
(\mathrm{dl} / \mathrm{g})\end{array}$ & $\mathrm{D}_{638} / \mathrm{D}_{690}$ \\
\hline $\mathrm{SnCl}_{4}-\mathrm{Ti}$ & 21 & 0.98 & 1.86 \\
$-\mathrm{V}$ & 8286 & 0.910 .62 & 1.79 \\
$\mathrm{GeCl}_{4}-\mathrm{Ti}$ & 5 & - & - \\
$-\mathrm{V}$ & 63 & 0.17 & - \\
$-\mathrm{V}(1: 4: 4)$ & 57 & 0.42 & - \\
$\mathrm{SiCl}_{4}-\mathrm{Ti}$ & 0 & - & - \\
$-\mathrm{V}$ & 45 & 0.45 & - \\
$\mathrm{BF}_{3}(\mathrm{ROH})-\mathrm{Ti}$ & 7 & - & - \\
$\mathrm{BF}_{3}\left(\mathrm{C}_{6} \mathrm{H}-\mathrm{OH}\right)-\mathrm{Ti}$ & 42 & 1.11 & 1.91 \\
$\mathrm{SeOCl}_{5}-\mathrm{V}(1: 4: 4)$ & 24 & 1.30 & 1.75 \\
$\mathrm{SbCl}_{5}-\mathrm{Ti}$ & 38 & 1.01 & - \\
$-\mathrm{V}$ & 20 & 0.68 & - \\
$\mathrm{VCl}_{4}-\mathrm{Ti}$ & 11 & 0.85 & - \\
$-\mathrm{V}$ & 15 & - & - \\
$\mathrm{VOCl}_{3}-\mathrm{Ti}$ & 39 & 0.28 & - \\
$-\mathrm{V}$ & 20 & 0.43 & - \\
\hline $\mathrm{ACl}_{3} \mathrm{AlBr}$ & 27 & 0.37 & - \\
\hline
\end{tabular}

$\mathrm{AlCl}_{3}, \mathrm{AlBr}_{3}, \mathrm{BCl}_{3}, \mathrm{SnCl}_{2}, \mathrm{TiCl}_{4}, \mathrm{MoCl}_{5}, \mathrm{WCl}_{6}, \mathrm{FeCl}_{3}$,-poor.

In any case basic additives are very important to modify the activity of triethylaluminium and are investigated extensively. As listed in Table 4, various kinds of polar compounds are available, although some of them destroy the catalyst. The action of basic additives is very delicate to the complexation of alkylaluminium. Among unsaturated hydrocarbons, ethers, nitrogen compounds, sulphoxides, ketones, phosphites, phosphates, esters, alcohols, amines and acids, ethers, especially THF, and esters are best.

It is important to note that the complexing agent modifies the catalyst nature, influencing the propagation reaction; tacticity of the polyvinyl chloride (PVC) unit, as well as monomer reactivity ratio, varies according to the complexing agents. Figure 1 shows the ir-absorption ratio $\mathrm{D}_{638} / \mathrm{D}_{690}$ as a syndiotacticity index of PVC and propylene (PP) contents in VC-PP copolymer; syndiotactic polymers possess a ratio of $D_{638} / D_{690} \gtrsim 2$.

These catalyst systems were found to be applicable to other monomers such as methyl methacrylate (MMA), acrylonitrile (AN), $i$-butyl vinyl ether $(i$-Bu VE) but not to styrene (ST) (Table 5). Styrene inhibits the polymerization of vinyl chloride. Copolymerization of vinyl chloride with $\alpha$-olefin is possible. 
JUNJI FURUKAWA

Table 4. VC-polymerization $\left(0^{\circ} \mathrm{C}, 20 \mathrm{~h}\right)$

$\mathrm{Et}_{3} \mathrm{Al} \cdot$ Base $-\mathrm{VO}(t-\mathrm{BuO})_{3}-\mathrm{SnCl}_{4}$

$1: 1$

Suitable

MMA, AN, $i$-BuVE

Unsaturated Compounds
Unsuitable

VAc, ST, 2-VPy, IP, Octene-2,

Phenylacetylene, Hexatriene,

Me-cyclohexene

$\mathrm{E}_{2} \mathrm{O},(i-\operatorname{Pr})_{2} \mathrm{O}, \mathrm{THF}$,

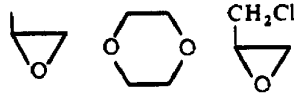

Ethers

(Allyl) ${ }_{2} \mathrm{O}$, Diglyme,
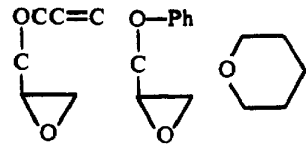

$\mathrm{CH}_{2}\left(\mathrm{OCH}_{3}\right)_{2}, \mathrm{CH}_{3} \mathrm{CH}(\mathrm{OR})_{2}$

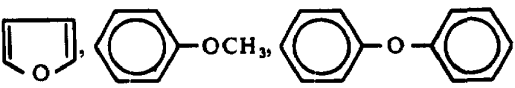

$\left(\mathrm{ClCH}_{2} \mathrm{CH}_{2}\right)_{2} \mathrm{O}$

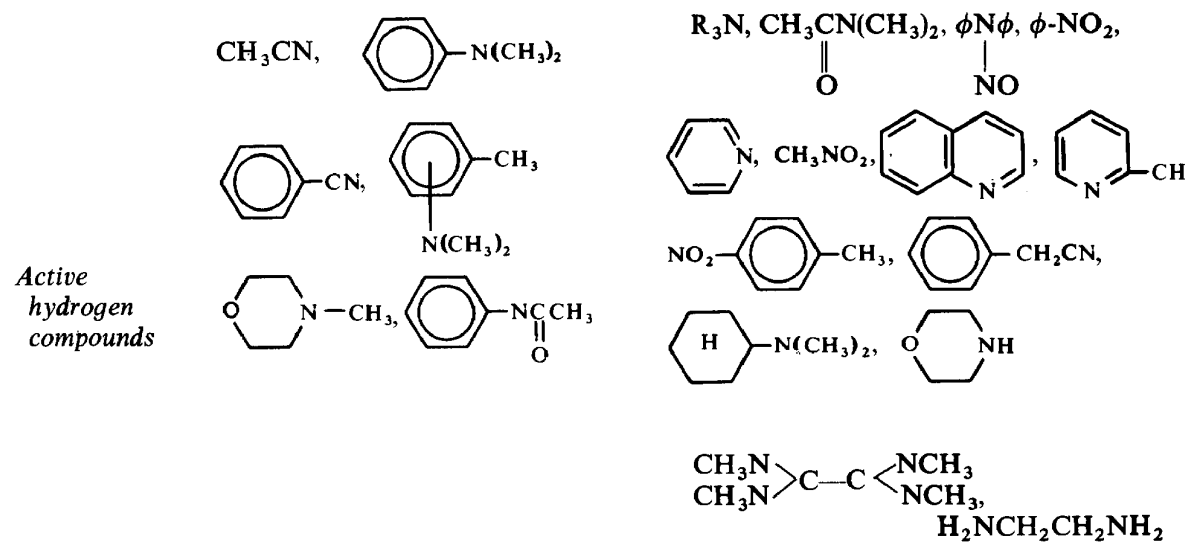

Sulphides

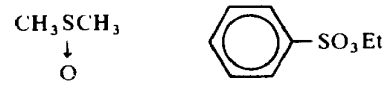

$(n-\mathrm{Bu})_{2} \mathrm{~S}, \prod_{\mathrm{S}},,(\mathrm{Allyl})_{2} \mathrm{~S}$,

$\phi_{2} \mathrm{~S}$ 


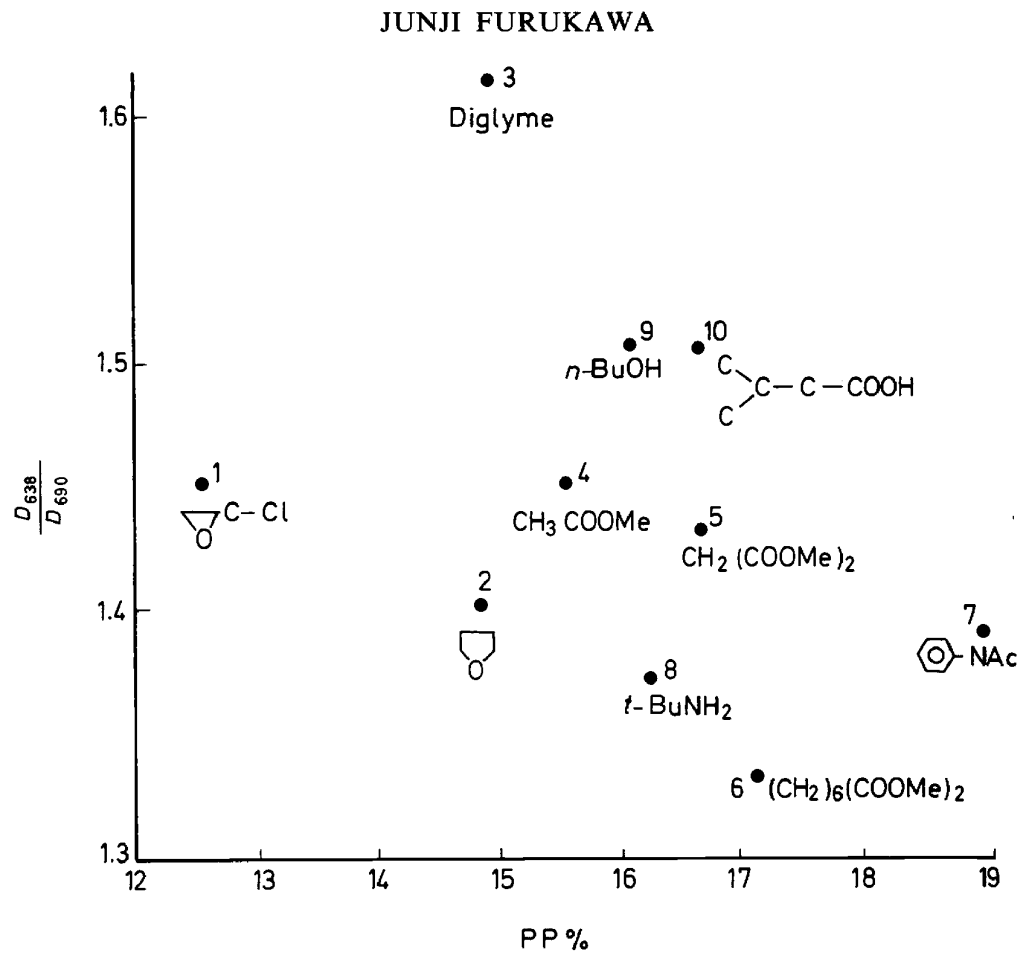

Figure 1. Base effect on tacticity and copolymerization. $\mathrm{VO}(t-\mathrm{BuO})_{3}-\mathrm{SnCl}_{4}-\mathrm{Et}_{3} \mathrm{Al}$. base. $(0 \sim$ r.t., $6 \sim 24$ hr. $)$

Table 5. Polymerization of other monomers

\begin{tabular}{|c|c|c|}
\hline & \multicolumn{2}{|c|}{$\left(0^{\circ} \mathrm{C}, 20 \mathrm{hr}\right.$, conv. $\left.\%\right)$} \\
\hline & $\mathrm{V}-\mathrm{SnCl}_{4}-\mathrm{Al}$ & $\mathrm{Ti}-\mathrm{SnCl}_{4}-\mathrm{Al}$ \\
\hline ST & 0 & 0 \\
\hline VC & 74 & - \\
\hline MMA & 75 & - \\
\hline AN & 71 & - \\
\hline$i$-BuVE & 94 & 100 \\
\hline$-\mathrm{CH}_{3}$ & 0 & - \\
\hline $7-\mathrm{CH}_{2} \mathrm{Cl}$ & 0 & - \\
\hline VC/ST & 0 & 0 \\
\hline VC-1-Butene & 20 & - \\
\hline VC-E & 5 & - \\
\hline$V C-P P-E$ & - & 13 \\
\hline
\end{tabular}




\section{COPOLYMERIZATION OF VINYL CHLORIDE}

Table 6. VC-PP copolymer

(Cat., $\mathrm{VO}(\mathrm{BuO})_{3}-\mathrm{SnCl}_{4}-\mathrm{AlEt}_{3} \cdot \mathrm{THF}, 0^{\circ} \mathrm{C}, 20 \mathrm{hr}$., conv. $31 \%$ )

Fractionation with benzene

\begin{tabular}{lccl}
\hline & $\begin{array}{c}\eta_{s p} / \mathrm{c} \\
(\mathrm{dl} / \mathrm{g})\end{array}$ & $\begin{array}{c}\text { PP } \\
(\mathrm{mole} \%)\end{array}$ & \\
\hline Original & 0.46 & 14.0 & \\
\hline $\begin{array}{l}\text { Insoluble 65 } \\
\text { Soluble 35 }\end{array}$ & 0.50 & 13.1 & ir not \\
different
\end{tabular}

$\operatorname{nmr}(\tau)$

\section{Copolymer}

Poly-PP

Poly-VC

$\begin{array}{cc}5.59, & 7.72,7.88 \\ 5.46, & -\overline{7},\end{array}$

$8.23,8.99$

$8.6,8.9$,

9.15

The homopolymers of vinyl chloride and methyl methacrylate are found, from ir analysis, to be rich in syndiotactic structure, as shown in Table 7.

Tetrahydrofuran is best as a complexing agent when an equimolar amount is used with respect to the alkylaluminium compound. Table 8 shows that

Table 7. Homopolymer-fractionation

\begin{tabular}{lllll}
\hline & & $\eta_{s p} / c$ & PP $\%$ & $\mathrm{D}_{638} / \mathrm{D}_{690}$ \\
\hline PVC (Ti-Cat.) THF & $\begin{array}{l}\text { solu. } \\
\text { insol. }\end{array}$ & 0.68 & - & 1.92 \\
& & 0.83 & - & 2.02 \\
\hline PMMA (V-Cat.) & & & $J$-value & $\mathrm{D}_{1058} / \mathrm{D}_{1379}$ \\
\hline
\end{tabular}

Table 8. Effect of THF on catalyst activity

\begin{tabular}{|c|c|c|c|c|}
\hline & $\begin{array}{l}\text { THF : A1 } \\
\text { (molar ratio) }\end{array}$ & $\begin{array}{l}\text { Conv. } \\
(\%)\end{array}$ & $\begin{array}{c}\mathrm{Cl} \\
(\%)\end{array}$ & \\
\hline \multirow[t]{3}{*}{ VC } & $0: 1$ & 4 & 16.3 & \\
\hline & $1: 1$ & 87 & 56.6 & $(=$ theoretical) \\
\hline & & & $\begin{array}{c}\text { PP } \\
(\text { mole \%) }\end{array}$ & $\eta_{s p} / c$ \\
\hline \multirow[t]{7}{*}{ VC-PP } & $\begin{array}{r}0: 1 \\
0.5: 1\end{array}$ & $\begin{array}{l}0 \\
0\end{array}$ & $\square$ & - \\
\hline & $1: 1$ & 27 & 14.9 & 0.31 \\
\hline & $1.25: 1$ & 16 & 14.1 & 0.32 \\
\hline & $1.75: 1$ & 7 & 13.5 & 0.30 \\
\hline & $2.0: 1$ & 2 & 15.1 & 0.29 \\
\hline & $6.0: 1$ & 0.6 & - & - \\
\hline & in $\mathrm{THF}$ solvent & 0.6 & - & - \\
\hline
\end{tabular}

DPPH stops polymerization, whereas HQ does not. 


\section{JUNJI FURUKAWA}

the catalyst with a THF : Al molar ratio of less than 1:1 produces only a poor yield of polymer, which is markedly dechlorinated. In the copolymerization of vinyl chloride and propylene, the catalyst with THF with more or less than an equimolar amount of alkylaluminium exhibits poor or no activity. Use of a large amount of THF as solvent results in unsatisfactory yield.

In this connection, the choice of solvent is very important. As summarized in Table 9 non-polar solvents such as $n$-hexane, $n$-heptane or toluene are available. Chlorinated hydrocarbons can also be used but active chlorine compounds such as carbon tetrachloride and tetrachloroethylene seem to act as chain-transfer agents yielding the polymer of low molecular weight and high chlorine content. Tetrahydrofuran used as a solvent lowers the polymer yield and the degree of polymerization.

Table 9. Solvent effect

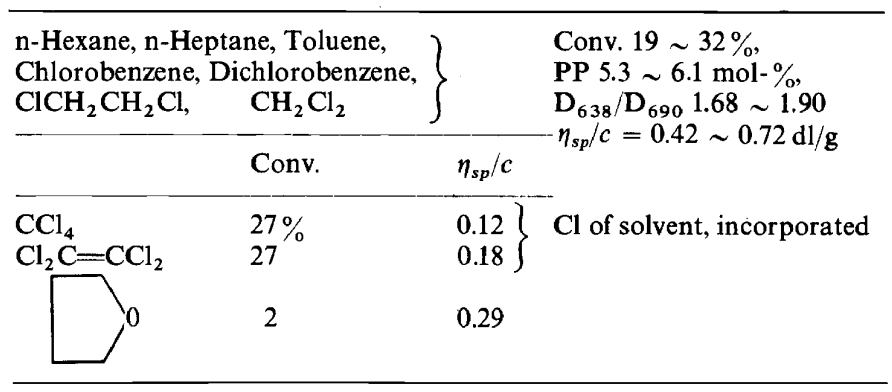

Another important factor is polymerization temperature; below $40^{\circ} \mathrm{C}$ the system is homogeneous and transparent and capable of yielding white polymers, whereas above that temperature it forms a brownish precipitate which gives polymer only in low yield. Consequently, the system composed of $\mathrm{VO}(\mathrm{BuO})_{3}-\mathrm{SnCl}_{4}-\mathrm{Et}_{3} \mathrm{Al}$. THF is different from a simple Ziegler catalyst, which is an insoluble catalyst activated by ageing. The temperature dependence of polymerization rate gives an activation energy for polymerization of $12 \mathrm{kcal} / \mathrm{mole}$ (Figure 2).

Figure 3 indicates that the polymerization rate is proportional to catalyst concentration. As shown in Figure 4 in the course of polymerization the intrinsic viscosity and the propylene content of the resulting polymer change

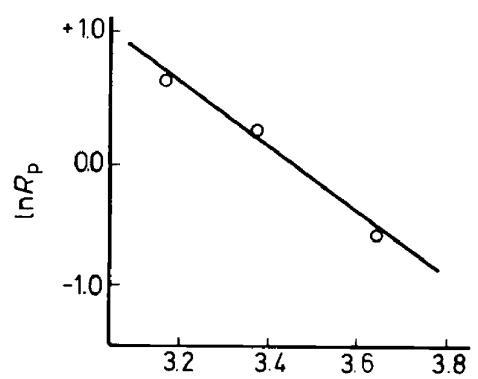

Figure 2. Arrhenius plot of VC-polymerization. 


\section{COPOLYMERIZATION OF VINYL CHLORIDE}

to some degree. These facts suggest a slight change of catalyst nature occurring during polymerization, because of the unstable nature of the catalyst.

Monomer reactivity is evaluated from the relation between polymer composition and feed monomer, shown in Figure 5. Contrary to the fact

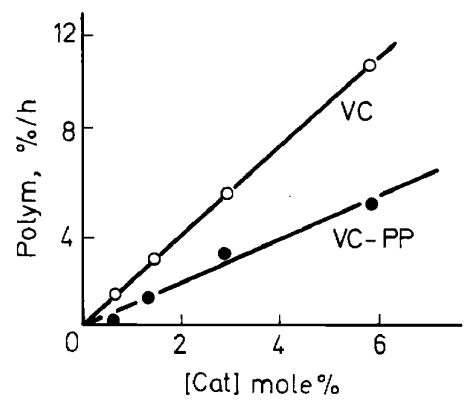

Figure 3. Effect of catalyst concentration on rate of polymerization

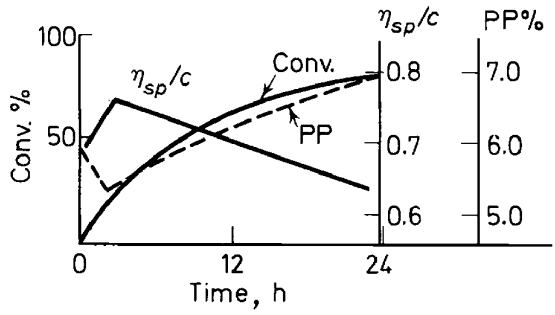

Figure 4. Polymerization time versus conversion, $\eta_{s p} / c$ and PP content of copolymer.

that the simple $\mathrm{Ti}\left(n-\mathrm{BuO}_{4}-\mathrm{EtAlCl}_{2}\right.$ system of Yamazaki ${ }^{2}$ produces a curve similar to that of AIBN-radical polymerization, the Ti- or V-compound$\mathrm{SnCl}_{4}-\mathrm{Et}_{3} \mathrm{Al} \cdot \mathrm{THF}$ system is quite different from the radical one. The incorporation of propylene in the copolymer is more difficult than the con-

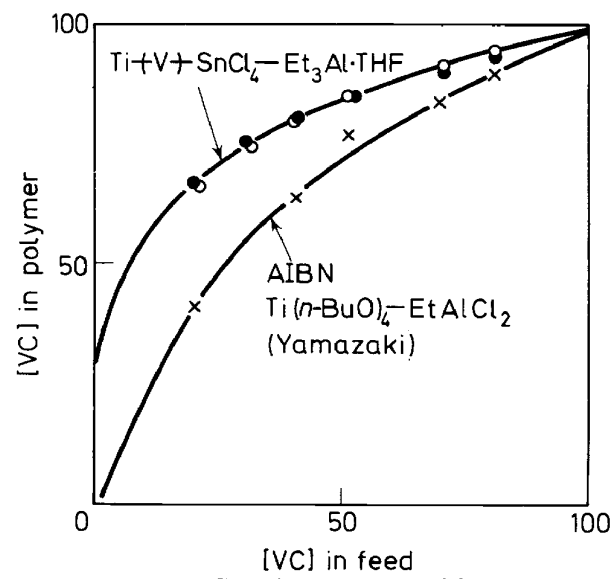

Figure 5. Copolymer composition curves. 


\section{JUNJI FURUKAWA}

ventional radical copolymerization. Our system does not fit the Lewis-Mayo two parameter relation.

According to the higher Markov-chain process, the monomer reactivity ratios $r_{\mathrm{vv}}$ and $r_{\mathrm{pv}}$ are estimated to be 4.85 and 0.34 , respectively, $r_{\mathrm{vp}}$ and $r_{p p}$ being about zero; this means a difficulty in incorporation of the propylene unit and a more complicated nature of catalyst, such as coordinated polymerization. Table 10 lists monomer reactivity ratios for several catalysts.

Table 10. Monomer reactivity ratio

\begin{tabular}{|c|c|c|}
\hline \multirow{4}{*}{$\left.\begin{array}{l}\mathrm{AIBN} \\
\mathrm{Ti}(\mathrm{BuO})_{4}-\mathrm{EtAlCl}_{2} \\
\mathrm{VO}(t \mathrm{BuO})_{3} \text { or } \mathrm{Ti}(n \mathrm{BuO})_{4} \\
-\mathrm{SnCl}_{4}-\mathrm{Et}_{3} \mathrm{Al} \cdot \mathrm{THF}\end{array}\right\}\left(60^{\circ} \mathrm{C}\right)$} & $\begin{array}{l}r_{\mathrm{vc}} \\
2.27 \\
235\end{array}$ & $\begin{array}{l}r_{\mathrm{pp}} \\
0.30\end{array}$ \\
\hline & 2.35 & 0.29 \\
\hline & $\begin{array}{l}r_{\mathrm{Vv}} \\
4.85\end{array}$ & $\begin{array}{l}r_{\mathrm{PV}} \\
0.34\end{array}$ \\
\hline & $\begin{array}{l}r_{\mathrm{VP}} \\
=0\end{array}$ & $\begin{array}{l}r_{\mathrm{PP}} \\
=0\end{array}$ \\
\hline
\end{tabular}

The interesting characteristic of our copolymerization is the influence of the catalyst or solvent on the tacticity of PVC units in the resulting copolymer. As shown in Table 11 the syndiotacticity expressed with $\mathrm{D}_{638} / \mathrm{D}_{690}$ is decreased by increasing the quantity of propylene or solvent in the polymerization mixture. The propylene content of the copolymer is also decreased by increasing the amount of added $n$-hexane.

Table 11. Tacticity of Poly-VC

(PP, $n$-Hexane decrease PVC-tacticity)

\begin{tabular}{rrrrr}
\hline VC & PP & \multicolumn{2}{c}{$n$-Hexane $\mathrm{D}_{638} / \mathrm{D}_{\mathbf{6 9 0}}$} & PP mol-\% \\
\hline 90 & 10 & 100 & 1.87 & 4.3 \\
85 & 15 & 100 & 1.84 & 6.4 \\
80 & 20 & 100 & 1.75 & 6.3 \\
70 & 30 & 100 & 1.72 & 9.4 \\
\hline 50 & 50 & 50 & 1.91 & 5.7 \\
50 & 50 & 100 & 1.90 & 5.3 \\
50 & 50 & 200 & 1.83 & 5.0 \\
\hline
\end{tabular}

This phenomenon might be ascribed to the diminishing effect of dilution on the coordination of aluminium compounds with vinyl chloride monomer.<smiles>C=C(Cl)[AlH]C(F)Cl</smiles>

dilution
$\mathrm{EtAlCl}_{2} \cdot \mathrm{THF}$<smiles>C=CCl</smiles>

THF $\cdot$ EtAlCl$_{2} \ldots$ Solvent

\section{COPOLYMERIZATION OF VINYL CHLORIDE WITH ACRYLONITRILE}

In the course of vinyl chloride polymerization, Hirooka ${ }^{7}$ reported the copolymerization of acrylonitrile, with use of organoaluminium compounds, 
to a $1: 1$ alternating copolymer of acrylonitrile with propylene or styrene. This catalyst was introduced to the alternating copolymerization of acrylonitrile with diolefin by the author. The system was much improved in activity and in prevention of gel-formation by the addition of a catalytic amount of vanadium compounds ${ }^{8}$. An equimolar amount of ethylaluminium dichloride is not necessary, our system is active enough with a catalytic amount of alkylaluminium. The regeneration of alkylaluminium proceeds by the cocatalyst action of the vanadium compound.

In this relation, we extend our research to the copolymerization of vinyl chloride and acrylonitrile with the catalyst composed of ethylaluminium dichloride with or without a vanadium cocatalyst. In both cases, acrylonitrile acts not only as a monomer but also as a complexing agent, if it is added to the ethylaluminium compound prior to mixing with vinyl chloride. Table 12 indicates the importance of the order of mixing of $\mathrm{AN}, \mathrm{EtAlCl}_{2}$, and $\mathrm{VC}$ components. Alkylaluminium reacts with vinyl chloride, unless it is pretreated with acrylonitrile. In these cases ethylaluminium dichloride is the best catalyst giving a white copolymer, whereas alkylaluminium monochloride or sesquichloride are scarcely active.

\begin{tabular}{|c|c|c|c|c|}
\hline & & $\mathrm{N}$ VC & C al & (g) \\
\hline \multirow[t]{2}{*}{$\mathrm{AN} \rightarrow$ al $\rightarrow \mathrm{VC}$} & 1 & $: 3$ & $: 1$ & 0.193 \\
\hline & 1 & $: 1$ & $: 1 / 2$ & 0.349 \\
\hline \multirow[t]{3}{*}{$\mathrm{AN} \rightarrow \mathrm{VC} \rightarrow$ al } & 1 & $: 3$ & $: 1$ & 0.021 \\
\hline & 2 & $: 2$ & $: 1$ & 0.016 \\
\hline & 3 & $: 1$ & $: 1$ & 0.033 \\
\hline
\end{tabular}

In the vinyl chloride-acrylonitrile copolymerization the alternating copolymerization is much affected by the amount of alkylaluminium in contrast to the butadiene-acrylonitrile copolymerization. The latter system always yields the 1:1 copolymer, independent of the amount of alkylaluminium, whereas the former gives random copolymers in the presence of a small amount of alkylaluminium. The alternating copolymer is obtainable only when a large amount of alkylaluminium is used. Figure 6 illustrates that the copolymer is not 1:1 but is rich in AN-content. In case A the amount of aluminium compound is kept constant with respect to total monomer and in case B with respect to AN monomer. In both cases AN-content of the polymer is higher than 50 per cent, depending on monomer composition. With increasing amount of alkylaluminium, the deviation of AN-content from 50 per cent is diminished and the use of an equimolar amount of aluminium compound with respect to $\mathrm{AN}$-monomer enables the formation of $1: 1$ copolymer irrespective of the feed monomer composition.

These facts may be explained by the assumption that the main reaction is the polymerization of the VC-AN monomer pair complexed by the charge transfer, although it is accompanied by its copolymerization with ANmonomer. In other words, the process is regarded as a copolymerization of the monomer complex (MC) with AN. Since the incorporation of an AN-unit 

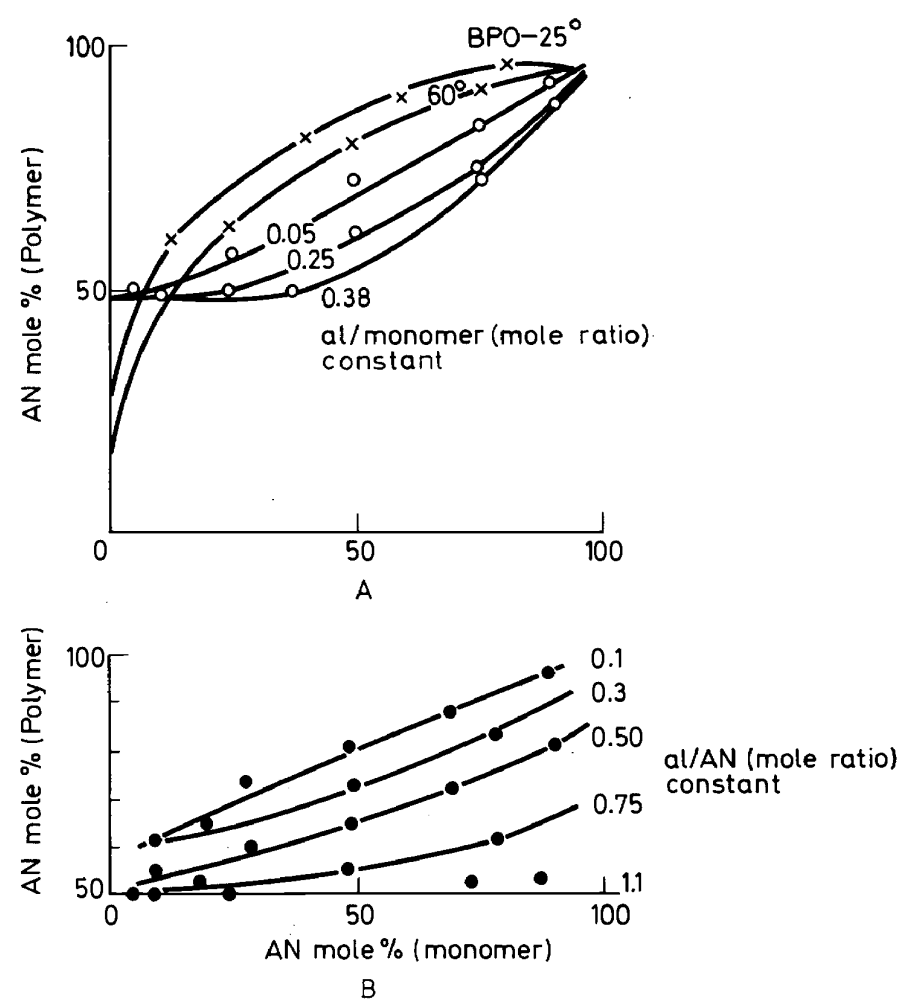

Figure 6. Effect of $\mathrm{EtAlCl}_{2}$ concentration on copolymer composition.

into the polymer is arising from the free $\mathrm{AN}$-monomer $\left(\mathrm{AN}_{f}\right)$ as well as $\mathrm{MC}$, it follows that:

$$
\frac{\mathrm{d}[\mathrm{AN}]}{\mathrm{d}[\mathrm{VC}]}=\frac{\mathrm{d}\left[\mathrm{AN}_{f}\right]+\mathrm{d}[\mathrm{MC}]}{\mathrm{d}[\mathrm{MC}]}=1+\frac{\mathrm{d}\left[\mathrm{AN}_{f}\right]}{\mathrm{d}[\mathrm{MC}]}
$$

Here, the following copolymerization equation and equilibrium equation for the MC-paired monomer are assumed. Accordingly,

$$
\frac{\mathrm{d}\left[\mathrm{AN}_{f}\right]}{\mathrm{d}[\mathrm{MC}]}=\frac{\left[\mathrm{AN}_{f}\right]}{[\mathrm{MC}]} \frac{r_{1}\left[\mathrm{AN}_{f}\right]+[\mathrm{MC}]}{\left[\mathrm{AN}_{f}\right]+r_{2}[\mathrm{MC}]}
$$

and

$$
[\mathrm{MC}]=\frac{K_{2}[\mathrm{al}][\mathrm{AN}][\mathrm{VC}]}{1+K_{1}[\mathrm{AN}]^{n}+K_{2}[\mathrm{AN}][\mathrm{VC}]},
$$

where [al] is the concentration of alkylaluminium and $n$ is assumed to be 2 . If [MC] is small and $K_{1}>K_{2}>1$, the copolymerization equation is simplified as follows:

$$
\frac{\mathrm{d}[\mathrm{AN}]}{\mathrm{d}[\mathrm{VC}]}=1+r_{1} \times \frac{K_{1}}{K_{2}} \times \frac{[\mathrm{AN}]}{[\mathrm{al}]} \times \frac{[\mathrm{AN}]}{[\mathrm{VC}]}
$$




\section{COPOLYMERIZATION OF VINYL CHLORIDE}

In fact, the experimental data fit the relationship; that is, the polymer composition is linearly correlated with monomer feed composition, depending on the excess amount of AN-monomer against alkylaluminium as shown in Figures 7 and 8 . Another possibility of the participation of AN-al complexed

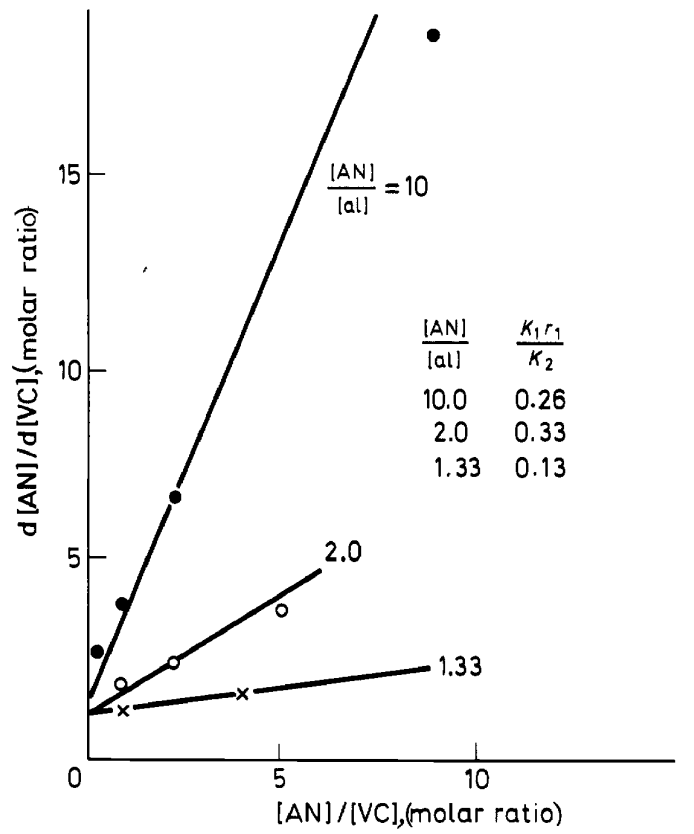

Figure 7. $[\mathrm{AN}] /[\mathrm{VC}]$ vs. d[AN]/d[VC] curves. (from Figure $6 B$ ).

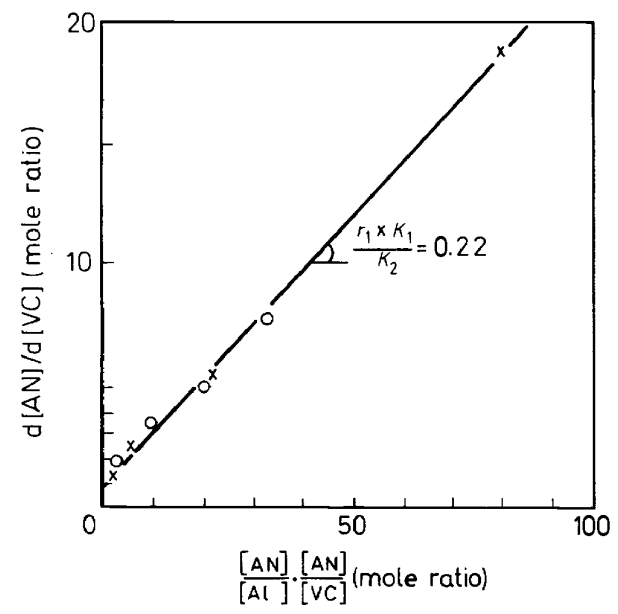

Figure 8. $[\mathrm{AN}] /[\mathrm{al}] \times[\mathrm{AN}] /[\mathrm{VC}]$ vs. d $[\mathrm{AN}] / \mathrm{d}[\mathrm{VC}]$ curve. (from Figure $6 A$ ). 
monomer may be ruled out, because of the large dependency on alkylaluminium concentration. In the latter case, the polymer composition is not affected by alkylaluminium concentration. Vinyl chloride monomer, either free or complexed, does not participate, since the VC-content in the polymer does not exceed 50 per cent. The mechanism involving the elimination of VC-units from the growing chain during the polymerization of VC-AN complexed monomer gives a similar result. However, it seems difficult to explain, by this mechanism, that the formation of the complete alternating copolymer occurs under the condition of al :AN being unity.

The difference between VC-AN copolymerization and BD-AN copolymerization is that the former produces random copolymer depending on the amount of catalyst, whereas the latter always gives $1: 1$ copolymer. This may be ascribed to the assumption that the formation and polymerization of VC-AN complex is small as compared with BD-AN complex. It should be noticed that vanadyl chloride acts as an effective cocatalyst, as shown in Table 13. The activity is much enhanced and enables polymerization at a temperature as low as $-78^{\circ} \mathrm{C}$.

Table 13. Effect of $\mathrm{VOCl}_{3}$ on copolymerization of $\mathrm{AN}$ with VC

$\left(\mathrm{AN}: \mathrm{VC}: \mathrm{EtAlCl}_{2}=1: 1: 1.1\right)$

\begin{tabular}{|c|c|c|c|c|c|c|c|c|c|}
\hline \multirow{2}{*}{$\frac{\mathrm{VOCl}_{3}}{\mathrm{EtAlCl}_{2}}$} & \multicolumn{3}{|c|}{$-78^{\circ} \mathrm{C}$} & \multicolumn{3}{|c|}{$-30^{\circ} \mathrm{C}$} & \multicolumn{3}{|c|}{$0^{\circ} \mathrm{C}$} \\
\hline & hr & Conv. & $(\mathrm{AN})$ & hr & Conv. & (AN) & hr & Conv. & $(\mathrm{AN})$ \\
\hline 0.0006 & - & - & - & - & - & 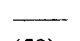 & C.15 & 53.5 & (49) \\
\hline 0.0014 & 18 & 12.0 & $(52.5)$ & 1 & 21.3 & (50) & - & - & $\overline{ }$ \\
\hline 0.1 & 4 & 24.2 & (51) & 3 & 49.5 & (49) & $\longrightarrow$ & $\longrightarrow$ & $\longrightarrow$ \\
\hline
\end{tabular}

However, the addition of vanadyl chloride and alteration of the polymerization temperature does not influence copolymerizability, as is illustrated in Figure 9.

\section{POLYMER PROPERTIES}

The properties of the vinyl chloride homopolymer and copolymer, prepared with organoaluminium catalyst, were investigated extensively from the industrial point of view.

As indicated in Figure 10 the glass transition temperature $T_{g}$ of PVC depends on the degree of polymerization or on the inherent viscosity, $\eta_{s p} / C$, of the polymer, but the $T_{g}-\eta_{s p} / C$ relation is not different from that for a

Table 14. Thermogravimetric and differential thermal analysis of Poly-VC

\begin{tabular}{lcc}
\hline & Commercial & V-Sn-(Al $\cdot$ THF) \\
\hline$\eta_{s p} / c(\mathrm{dl} / \mathrm{g})$ & 0.5 & -0.4 \\
$T_{g}\left({ }^{\circ} \mathrm{C}\right)$ & 83.5 & 84.5 \\
$T G A\left({ }^{\circ} \mathrm{C}\right)$ & 295 & 316 \\
$(10 \%$ loss $)$ & 276 & 287 \\
$D T A\left({ }^{\circ} \mathrm{C}\right)$ & \\
\hline
\end{tabular}


COPOLYMERIZATION OF VINYL CHLORIDE

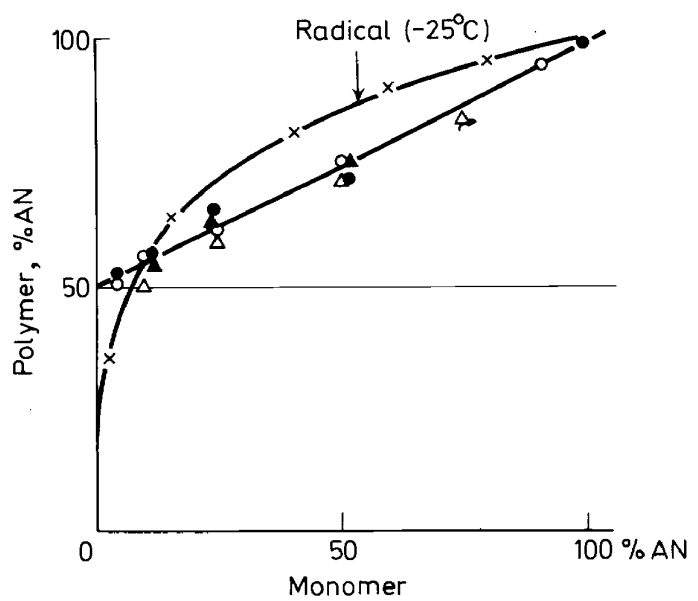

Figure 9. Copolymer composition curves

\begin{tabular}{|c|c|c|}
\hline & $-78^{\circ} \mathrm{C}$ & $-30^{\circ} \mathrm{C}$ \\
\hline $\begin{array}{c}(\mathrm{VC}: \mathrm{AN}): \mathrm{EtAlCl}_{2} \\
20\end{array}$ & 0 & - \\
\hline $\begin{array}{ccc}(\mathrm{VC}: \mathrm{AN}) & \mathrm{EtAlCl}_{2}-\mathrm{VOCl}_{3} \\
20 & 1 & 0.05\end{array}$ & $\Delta$ & $\Delta$ \\
\hline
\end{tabular}

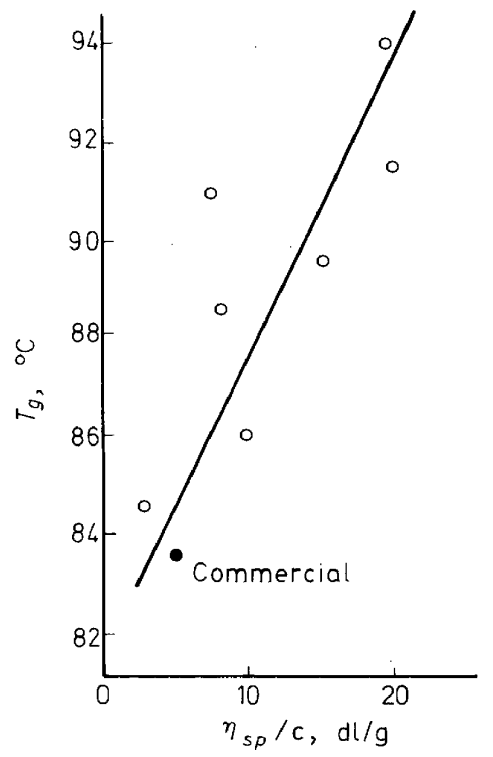

Figure $10 . \eta_{s p} / c$ vs. $T_{g}$ curves of poly-VC 


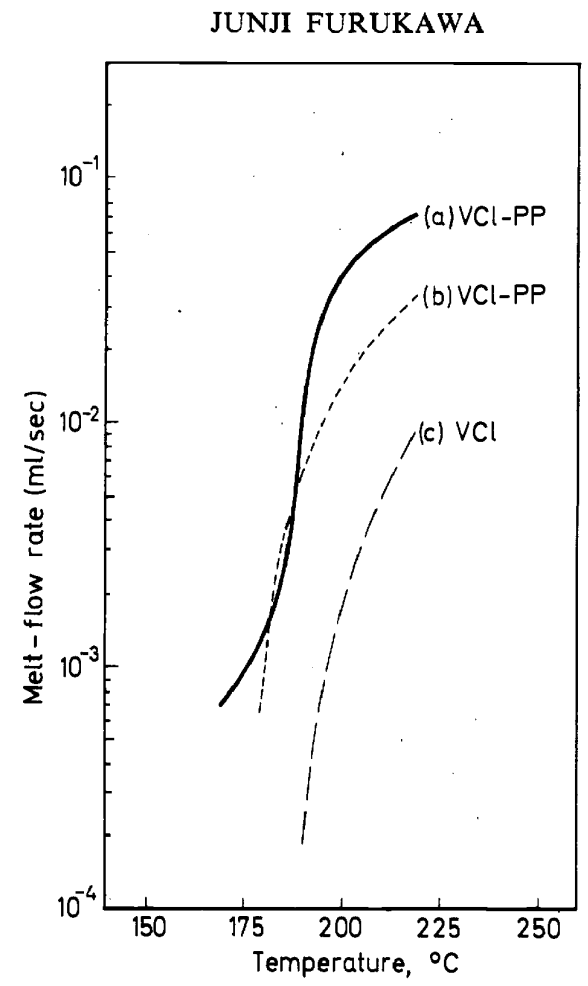

Figure 11. Melt-flow property of VC-PP copolymer and of VC homopolymer.

(a) $\mathrm{VCl}-\mathrm{PP}$ copolymer by the $\mathrm{VO}(\mathrm{Ot}-\mathrm{Bu})_{3}--\mathrm{SnCl}_{4}--\mathrm{Et}_{3} \mathrm{Al} \cdot \mathrm{THF}$ catalyst; (b) $\mathrm{VCl}--\mathrm{PP}$ commercial copolymer; (c) VCl commercial homopolymer.]

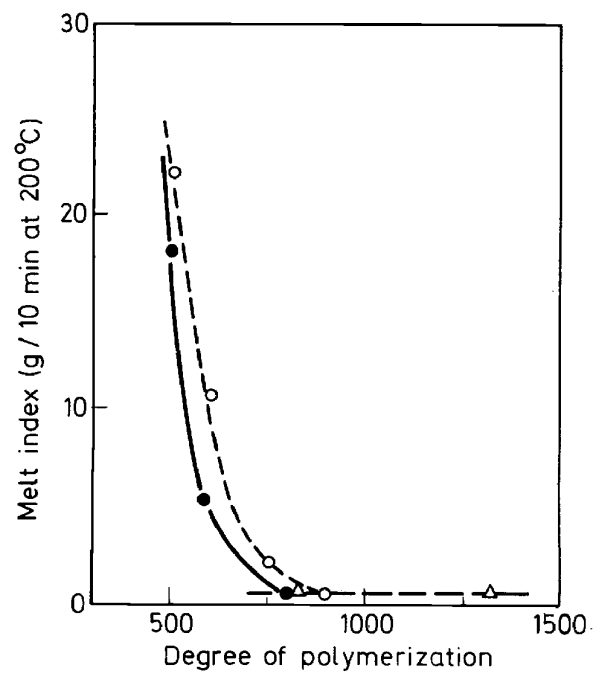

Figure 12. Melt indices of VC-PP copolymer and of VChomopolymer.

- - Copolymer by $\mathrm{V}-\mathrm{Sn}-\mathrm{Al}$ catalyst.

O---O: Commrercial copolymer.

$\triangle--\triangle$ : Commercial VC homopolymer. 


\section{COPOLYMERIZATION OF VINYL CHLORIDE}

commercial polymer. Some differences were observed in thermogravimetric and differential thermal analysis as shown in Table 14.

The vinyl chloride-propylene copolymer prepared with our catalyst possesses a high melt flow property as compared with the homovinyl chloride. But this property is common with the commercial copolymer prepared by the radical polymerization. Figure 11 shows the above situation.

Figure 12 is the melt index and Figure 13 is the rate of spiral flow. Both

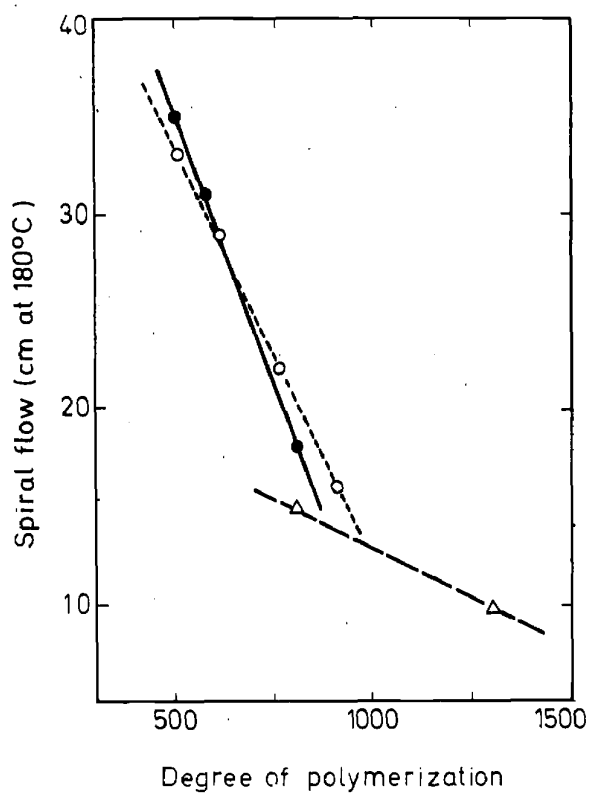

Figure 13. Spiral flows of VC-PP copolymer and of VChomopolymer.

$-\quad \bullet, 0--0, \Delta-\Delta$, See Figure 12

are demonstrated as a function of the degree of polymerization $(\bar{P})$. Here, both the copolymers show a higher melt index than the homopolymer.

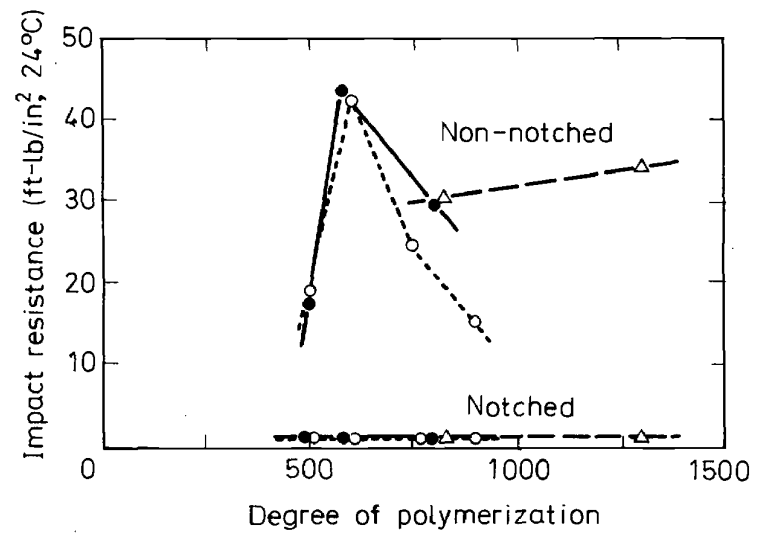

Figure 14. Impact resistance of VC-PP copolymer $-0,0--0, \triangle-\longrightarrow \triangle$, See Figure 12 
JUNJI FURUKAWA

Table 15. Assignment of nmr spectra of AN-VC copolymer

\begin{tabular}{|c|c|c|}
\hline $\begin{array}{l}\text { Signal } \\
\text { No. }\end{array}$ & $\begin{array}{l}\text { Chemical shift } \\
(\tau)\end{array}$ & Assignment \\
\hline 1 & 5.76 & $\underline{\mathrm{H}}-\mathrm{C}-\mathrm{Cl}$ \\
\hline 2 & 6.85 & $\underline{\mathrm{H}}-\mathrm{C}-\mathrm{CN}$ \\
\hline 3 & 7.09 & Water \\
\hline 4 & 7.56 & Solvent \\
\hline 5 & 7.79 & $-\underset{\mid}{-\mathrm{CH}}-\underline{\mathrm{H}}_{2}-\underset{\mathrm{CN}}{\mathrm{CH}}-$ \\
\hline 6 & 7.93 & $-\underset{\mathrm{CN}}{\mathrm{C}} \mathrm{H}-\underline{\mathrm{CH}}_{2}-\underset{\mathrm{CN}}{\mathrm{CH}}-$ \\
\hline
\end{tabular}

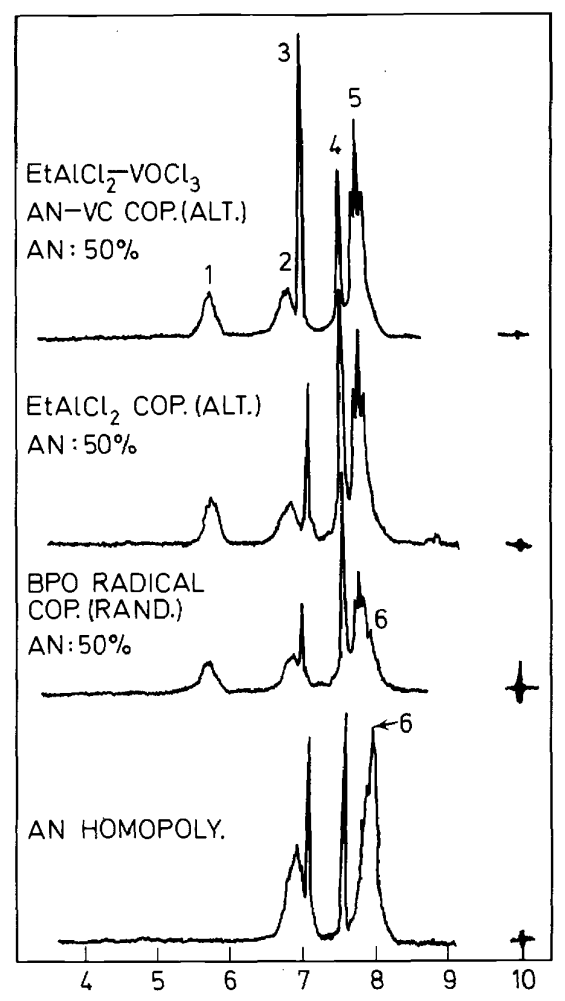

Figure 15. Nmr spectra of $\mathrm{AN}-\mathrm{VC}$ copolymer. $\left(100 \mathrm{MHz}\right.$. Solvent, $\left(\mathrm{CD}_{3}\right)_{2} \mathrm{SO}_{i}$; concentration, $6 \%$; reference, TMS; temperature, $80^{\circ} \mathrm{C}$.) 


\section{COPOLYMERIZATION OF VINYL CHLORIDE}

Figure 14 shows the impact resistance as a function of the degree of polymerization. The copolymers possess different values from the homopolymer.

The vinyl chloride-acrylonitrile alternating copolymer seems to be interesting and versatile because it shows characteristic behaviour due to the absence of AN-AN or VC-VC diad, as summarized in Table 15.

Figure 15 is the nmr diagram, which shows that the copolymer is alternating.

\section{ACKNOWLEDGMENTS}

This work was carried out in cooperation with Messrs. Y. Iseda, J. Yamauchi, and E. Kobayashi. Technical investigations of the polymer were carried out with the cooperation of Messrs. N. Terui and A. Miyagi at the Research Centre of the Bridgestone Tire Co.

\section{REFERENCES}

${ }^{1}$ A. Misono, Y. Uchida, and K. Yamada. Preprints of International Symposium on Macromolecular Chemistry Tokyo-Kyoto, I-132(1966).

2 N. Yamazaki, K. Sasaki, and S. Kambara. Preprints of International Symposium on Macromolecular Chemistry Tokyo - Kyoto, I-128(1966).

3 A. Misono, Y. Uchida, K. Yamada, and T. Saeki. Bull. Chem. Soc. Japan 41, 2995 (1968).

4 A. Misono, Y. Uchida, and K. Yamada. J. Polymer Sci. B5, 405 (1967).

5 D. S. Breslow, D. L. Christman, H. H. Espy, and C. A. Lukach. J. Appl. Polymer Sci. 11, 73 (1967).

6 (a) J. Furukawa, R. Yamamoto, Y. Iseda, K. Haga, N. Kataoka, and A. Yamamoto. Japan. Patent Application 1967-10441 (Feb. 20, 1967).

(b) N. Yamazaki, K. Sasaki, and S. Kambara. J. Polymer Sci. B2, 487 (1964).

(c) A. Misono, Y. Uchida, and K. Yamada. Bull. Chem. Soc. Japan 39, 1822 (1966).

7 K. Nakaguchi, M. Kawasumi, M. Hirooka, and H. Yabuuchi. Japan. Patent Application 1964-47354 (Aug. 18, 1964).

8 J. Furukawa and Y. Iseda. J. Polymer Sci., B7, 47 (1969). 